\title{
Dokia Humenna's Depiction of the Second World War and the OUN in Khreshchatyi iar: How Readers Responded
}

\author{
Myroslav Shkandrij \\ University of Manitoba
}

\begin{abstract}
When Dokia Humenna's novel depicting the Second World War, Khreshchatyi iar (Khreshchatyk Ravine), was published in New York in 1956, it created a controversy. Readers were particularly interested in the way activists of the OUN were portrayed. This article analyzes readers' comments and Humenna's responses, which are today stored in the archives of the Ukrainian Academy of Science in New York. The novel is based on a diary Humenna kept during the German occupation of Kyiv in the years 1941-1943.
\end{abstract}

Keywords: Dokia Humenna, Khreshchatyi iar, Second World War, OUN, Émigré Literature, Reader Response

Tn the 1950s and 1960s the Ukrainian émigré readership responded strongly to the publication of Dokia Humenna's Khreshchatyi iar (Kyiv 1941-43: Roman-khronika (Khreshchatyk Ravine [Kyiv 1941-43]: A NovelChronicle, 1956). Published in New York and based on a diary that the author kept during the war, the book deals with the German occupation of the Ukrainian capital. It provides an account of fluctuations in the city's collective psyche through the ebb and flow of opinion and rumour. It is particularly memorable for the portrayal of Jewish protagonists, Soviet apologists and individuals committed to Ukrainian independence. Humenna began her literary career in the late 1920s and in the 1930s was ejected from the Writers' Union for criticizing Soviet policies and the socially privileged strata. During and after the Second World War, she was both anti-Nazi and anti-Soviet, and voiced criticism of the arrogant behaviour displayed by some supporters of the OUN (Organization of Ukrainian Nationalists). These had arrived from Galicia and Central European countries and attempted to organize literary and political groups in Kyiv. Mariana, Humenna's alter ego in the novel, rejects their narrow

The author would like to thank the Canadian Institute of Ukrainian Studies and the Faculty of Arts, University of Manitoba, for funding that enabled research on this article to be completed. 
concept of the nation and is offended by their dismissive attitude toward local "Sovietized" Ukrainians. Unlike these newcomers, she views her nation in far more inclusive terms - as the product of several thousand years of evolution, over which time many waves of migration have interacted. The novel contains portraits of well-known writers like Olena Teliha, Ulas Samchuk, Arkadii Liubchenko and Leonid Pervomais'kyi, but the main focus is on clashing attitudes among ordinary citizens. It remains one of the best accounts of the occupation and provides remarkably frank descriptions of popular attitudes towards various groups: Germans, Jews, pro-Soviet citizens and activists of the OUN. ${ }^{1}$

The novel's appearance in 1956 caused a sensation. Many readers in the West who had survived the war and occupation were hungry for a literature that reflected their experience. However, in émigré novels by writers like Ulas Samchuk and Stepan Liubomyrs'kyi perceptions of the war and the role of the OUN had been assimilated to a less problematic narrative of heroic struggle for independence. Humenna challenged and complicated this narrative. Moreover, the novel appeared at a time when émigré writers were mounting a sustained critique of the OUN's pre-war ideology, a process begun in the Displaced Persons (DP) camps in the years 1945-48, where it was led by the literary organization MUR (Mystets'kyi Ukrains'kyi Rukh - Artistic Ukrainian Movement). 1956 was the year in which a democratizing wing split from the OUN-B (the Bandera faction) and created a separate party, one that adhered to a democratic platform and accused Bandera's supporters of retaining an attachment to the leader cult and dictatorial methods that characterized the 1930s. And finally, 1956 was also the year in which the New York Group, a young generation of modernist writers, began publishing works that focused on personal experience and subjective impressions, ignoring the political imperative that had been dominant in the literature of the 1930s and 1940s. In this context, it was perhaps inevitable that Humenna's novel would be viewed by many as a polemic directed against the OUN or a demonstration of modernist writing.

The most contentious issue was the characterization of OUN activists. This is evident from the correspondence received by Humenna in response to her novel. This correspondence, containing close to a hundred letters, postcards, notes and reviews, can be found in her archive at the Ukrainian Academy of Sciences in New York. Humenna responded to most letter-

\footnotetext{
1 For a discussion of the novel and its relationship to Humenna's diary, see my "Dokia Humenna's Representation of the Second World War in Her Novel and Diary." For an adapted version of the latter, see my Ukrainian Nationalism: Politics, Ideology, and Literature, 1929-1956, 253-67.
} 
writers, providing longer answers to the more substantive comments. These comments and Humenna's responses are summarized in the pages that follow. The same arguments and the same views, whether positive or negative, were frequently repeated, both in letters by ordinary readers and in published reviews. Humenna kept a number of negative reviews in her archive, along with her public responses or, in a few cases, with comments she had made in the margins. Since there is a high degree of repetition in the comments by both "consumers" and "professional critics" they have been treated together. The focus throughout is, of course, on the "real" reader, who, as Humenna repeatedly indicates, is not always a "competent" reader, insofar as he or she often misread the text or the author's intentions.

Letters to the author contained in the archive can be approximately evenly divided between those with positive and those with negative things to say about the book. ${ }^{2}$ Readers most frequently voiced opinions on the different ways the author portrayed Eastern Ukrainians (those who until 1941 had been under Soviet rule) and Western Ukrainians or émigrés who returned from Central Europe to Ukraine during the war. American readers who had come from Western Ukraine (Galicia, Bukovyna and Transcarpathia) often disagreed with Humenna's portrayal of OUN supporters specifically, but some took offence at the general depiction of Galicians and Western Ukrainians or émigrés. On the other hand, readers from Eastern Ukraine, especially eyewitnesses to Kyiv's occupation, were generally enthusiastic about the book and the way it characterized people. Although the Western-Eastern divide was not a rigid one, more often than not "Easterners" were not supporters of the OUN. They tended to belong to other "nationalist" parties in the emigration, such as the social-democratic URDP (Ukrainian Revolutionary Democratic Party - Ukrains'ka Revoliutsiina Demokratychna Partiia). Among the responses, which varied from short notes to letters of several pages, there were none written by supporters of the Soviet regime. Some letter writers identified themselves as being far removed from the profession of writer or critic, revealing that they had decided to contact the author after being powerfully moved by reading the book. Published authors and critics among the letter writers included the writer Halyna Zhurba, the critics Hryhorii Kostiuk and Yurii Lavrinenko (all "Easterners"), and the historian Lev Shankovs'kyi (a "Westerner").

\footnotetext{
2 All the following letters quoted are available in the Dokia Humenna archive, Ukrainian Academy of Sciences in the U.S. (UVAN), New York and are in the archival file "Khreshchatyi iar retsenzii, vidhuky, lysty vid chytachiv, vidozvy, laiky, 1956." Henceforth DHA.
} 
The most enthusiastic responses came from "Easterners" who had survived the occupation. One described devouring the book "in a single breath" (DHA, Sofiia Haievska, 21 Feb. 1956). These readers found the detail authentic and vivid, and the revelations of human baseness entirely appropriate and credible. Although they sometimes found the novel's integration of different voices and viewpoints a problem, they had no trouble understanding that Humenna had produced a polyphonic account of life in extreme circumstances, and was developing "a new style" of narrative (Sofiia Haievska). They were often pleased to find their own experience at least partially validated. One wrote:

This is the first time in my life that I have read such an unbiased, objective, truthful, sincere book about our recent past, in fact our contemporary reality. Your Iar [Khreshchatyi Iar] is a priceless contribution to our literature, ... this is a moment in the history of our people that cannot (and should not) be deleted, it is a work that will stand guard over the truth.... I recalled how I went under a false name to get papers freeing people from [forced labour in] Germany. I remembered how I stole blank forms, placing the required stamp on them, so as to hide those who had not been given permission. I remembered how we hid our Jewish neighbours with their small children from the "visits" of Germans, until they could be freed. (DHA, Oksana Bryn', 18 April 1956)

At the other extreme, a number of readers (generally those who were not sympathetic to her portrayal of "Westerners") found the text confusing to the point of being incomprehensible. Several called the book "too drawn out" (DHA, H. Hordiienko, 23 Nov. 1957). Some admitted that they lacked the patience to follow the interweaving of different lives, and voiced disappointment that a simpler, more easily graspable message had not been presented. Occasionally, the author's style was compared unfavourably with Ulas Samchuk's Piat' po dvanadtsiatii (Five After Twelve, 1954), which was "shorter and more condensed" (DHA, I. Krylova, 2 Feb. 1956). Samchuk was, of course, an OUN loyalist who remained close to the Mel'nyk faction during the war. This book is a memoir in which he describes his experience and that of other refugees during the fall of the Third Reich.

For most readers, however, the question of style was a secondary consideration. They were riveted by the description of occupied Kyiv and the behaviour of the OUN's supporters. A number of correspondents revealed that they had during the war been sent by the OUN to build its network in Eastern Ukraine. They sometimes felt that as an "Easterner" the author was biased against them and Western Ukrainians in general. These correspondents frequently pointed out that the young men who went east were idealists, who risked and frequently lost their lives in German or 
Soviet torture chambers, prisons or before firing squads. They felt that the author failed to appreciate the strength of conviction, self-sacrificing spirit and devotion to the cause shown by this youth. The book clearly represented a challenge to the way they viewed the war, especially in complicating the narrative of national liberation they had internalized and one that a less demanding literature was at the time reinforcing.

The strongest critique of "Eastern" bias was written in 1960 by Lev Shankovs'kyi, who had travelled with the expeditionary groups or task forces (pokhidni hrupy) that followed the German advance into Ukraine and in 1958 authored the now classic account of how these groups met resistance to their ideology among "Easterners." In his letter to Humenna, he complained that she had slandered Galician nationalists. The novel proved to him that she did not understand the psychology of Western Ukrainian or émigré nationalists. He found false and unjust her image of Olena Teliha and other nationalists who made their way to Kyiv from Prague (the largest and most active centre for interwar émigrés) and other European cities, although he was prepared to grant a sense of authenticity to the portrayal of the other figures:

In general allow me to say openly that I consider the pretensions of our dear brothers and sisters from Central and Eastern Ukraine to monopolize [our] understanding of Soviet reality and the psychology of its people to be a partial misunderstanding, in so far as these brothers and sisters forget that their knowledge of the USSR dates back almost twenty years (therefore is essentially émigré), and if they do not renew this knowledge by maintaining contact with the Soviet press and publications, they in essence know less than those who have never perhaps been in the USSR, have never seen a "Soviet" with their own eyes, but study Soviet problems and analyze them according to scholarly methods....

Your Khr. Iar showed me at least that you completely fail to understand the psychology of Western Ukrainians or émigré nationalists, even if you have perhaps tried to grasp it. I will always consider your portrait of the Kyivite Olena Teliha entirely false and to a certain degree an offence against her name, and view the contrived and artificial figures of other Ukrainian nationalists in the same way. (DHA, Lev Shankovs'kyi, 10 Nov. 1960)

Humenna replied that she found confirmation of her views in Shankovs'kyi's own Pokhidni hrupy (Expeditionary Groups, 1958), especially in his account of how these groups-sent to conduct propaganda work and establish an underground network-were confronted by "Easterners." When asked what social order they planned to institute, the OUN activists were unable to respond. This, she argued, was the main cause of misunderstandings between West and East. In the novel, she aimed to record this conflict, to provide the "Eastern" point of view, and to ignore the 
hackneyed portrayal of the "nationalist hero" from Western Ukraine. In time, she suggested, the new arrivals and the locals would have become better acquainted, would have gained a firmer understanding of each other's history, and as a result many mistakes made in the early months would have been corrected:

You recount how all the expeditionary groups reported that the local population first asked about the future social order, the method of agricultural work and so on, and that the expeditionary groups were surprised by this because they did not have prepared answers....

Or maybe [the issue is that] my Khr. iar gives the events from the point of view not of a nationalist hero, but from that of an aboriginal, a local.... But why not listen to the way these locals [obyvatel'] think and feel, why shouldn't their voices also be heard?

... If you think that my point of view ... is a personal one that cannot "understand the depths of the problem," then explain to me why I have so many expressions of support from readers with a Soviet background? They say that I grasped their thoughts. Does this part of the public not have the right to be heard? And what harm is there if someone is allowed to see how they appear to an observer, and not the way they would like to think they appear?...

Humenna argued that, although the activity of the nationalist underground was indirectly depicted, the book was primarily about Kyiv and "therefore the nationalists receive as much space as they occupied in reality." These same arrivals from the West, after greater exposure to Eastern Ukraine, would not have seen a "bolshevized" person in everyone who failed to use nationalist phraseology, and the locals in their turn would have recognized that "behind the unaccustomed phrase" lay "sincere dedication and selfsacrifice on Ukraine's behalf." As examples of the fatal "Western" inability to read the local situation, the author noted Teliha's mistake in hiring Inna Rohals'ka as her personal secretary and most trusted figure, her selection of Yurii Muzychenko as a protege, and her snubbing of Pavlo Nechai:

[W] hen Teliha was arrested [Rohals'ka] became secretary to the editor of Nove ukrainske slovo (Budik). I met her once and she began to brag that she had "an uncle in Leipzig" and that she was already a Volksdeutscher, because her grandmother had been German. I asked: "Why aren't you speaking Ukrainian? This is the first time I have heard you speak Russian..." Her answer: "It is dangerous now!"

I can explain this turncoat's success in winning Teliha's trust only by the fact that the latter was not familiar with the real situation, could not assess with whom she should be allied. This was her error; but at the same time Khr. iar does not strip her of her heroism. I can bring further examples of such errors, but this will take time and space. I am responding to your 
charge because you are an intelligent man and I would like you to understand how wrongly you interpret Khr. iar. It is an attempt at an objective view, written in Kyiv but through the eyes of a local inhabitant. (DHA, Lev Shankovs'kyi, Humenna's response, 18 Feb. 1960)

Another reader wrote that he had devoured the book, but was irked by some details. German officers, according to him, never wore white gloves, except perhaps in parades on Berlin's Unter den Linden during the changing of the guard by the monument to the Unknown Soldier. This detail was for him symptomatic: he objected to the repetition of white gloves as part of Humenna's "angry sarcasm" toward everything German, and to her association of Ukrainian nationalists with German money and support. He pointed out that the mercenary behaviour of the Eastern Ukrainian intelligentsia was, if anything, even more depressing: "Mistrust, bribery, denunciation, slavish bending of the spine before every passing German soldier... was this not horrifying for us?" The idealistic attitudes of those who were educated west of the border, he wrote, found such servility offensive. Like a number of other readers, he associated the views expressed by some protagonists with the author's. For example, he was offended that a character made fun of the men from Lviv who declared independence on June 30,1941: "No, there is a little too much ridiculing and too many jokes at the expense of the heroic deaths suffered by these people, who gave their lives for a better tomorrow in what is after all their and your homeland!" Even though he admired much in the work, he concluded: "I will not give the book for reading to the young scouts, whose leader I am” (DHA, Ivan R. Kostiuk, 16 Mar. 1956). Humenna responded:

One of the main purposes of my work is to show the complex process that had taken place in the souls of ordinary Soviet people, who somehow survived those twenty-three years, grew up there, and inevitably were products of Soviet moulding. These people knew nothing else; they were stuffed with daily press and radio offerings, which willy-nilly crawled into their ears. Every day they were told about "bourgeois nationalists in the emigration" and when the USSR's collapse came, they continued to move within the sphere of the assimilated phraseology.... An enormous change is occurring in their souls, as they gradually and painfully free themselves from the chains of Sovietism.... I do not understand why you polemicize with statements made by characters who are undergoing this process of digesting and assimilating new content. Why do you concentrate only on what you dislike and select only quotations that completely change my work's meaning? Dear Sir, Soviet criticism beat me with its cudgels in exactly the same way, calling me a broadcaster of bourgeois nationalism, a slanderer of Soviet reality, etc. I see no difference in your method of criticism.... Today, in my old age I would like to speak freely, without fear 
of censorship, or accusatory "lawyers." ... You are upset because you are not presented as icons, but as living beings with inherent traits.... As for the term novel-chronicle, the chronicle part signifies that a novelistic form has been selected in which events follow in chronological order. It does not mean that I have agreed to provide a history. Histories are written on the basis of documents, and I did not do this. (DHA, Ivan R. Kostiuk, Humenna's reply, n. d.)

In a similar vein, another correspondent complained that the author had done a grave disservice to the nationalist youth of Western Ukraine, who had sacrificed everything "in order to make their way secretly past enemy posts and to go on foot, often cold and hungry, to our golden-domed capital, or to other towns in Central and Eastern Ukraine." The writer continued:

They went with a single purpose, to join the ranks of those who were fighting for and building a Ukrainian state, which in their imaginations and dreams was to be resurrected on their native soil. I know this youth well and bow my head before their idealism, dedication and strength of spirit. They did not go to be bosses. They went to help in any way necessary. They took the steering wheel in their hands only where none of the local people were capable of doing so, and they acted as they knew best. These were not statesmen, diplomats; they were idealistic, completely dedicated youth.

And the fact that almost none of this idealistic youth returned to their family circles, because they were nearly all murdered by the enemy and died with Ukraine's name on their lips, should restrain you from characterizing them as you do.

The same can be said of the declaration of an independent Ukrainian state, which took place on June 30, 1941 and which, whether one likes it or not, is inscribed in the pages of national history.... In my view this was one of the brightest events of the recent war in our land. And it makes little difference whether a hundred people were present at the declaration, or more; nor is it important whether the individual who made the announcement "was a youth or no longer really a youth." The heroic act of the young men who died at Kruty has also been written into our history in golden letters because they were all young men and unfortunately there were not many like them. And no one today dares to speak of this event with the same dose of ridicule that you express concerning our latest renewal of independence.... To reduce this fact to a "comedy" staged by people who desired to "spend a night in prison because this was chic" testifies either to your lack of information or your ill will.

We have become accustomed to hearing similar thoughts and expressions at various party gatherings, and to reading . . . about Ukrainian "fascists" particularly in propaganda literature from behind the iron curtain. We do not wonder at this. However, we are astonished that a prominent Ukrainian writer has shown so little loyalty in her approach to 
historical events in Ukrainian life. . . . I protest against the tendentious distortion of facts and ideas that were and remain sacred for the Ukrainian people. (DHA, Maria Lohaza, 14 Apr. 1956)

These comments, which are particularly resonant in light of present debates over the heroization or deheroization of the $0 \mathrm{UN},{ }^{3}$ were answered by Humenna in the following way:

I would like to assure you that there is neither tendentiousness nor ridicule in the book, but only a desire to dispassionately fix the living, unvarnished picture of the contemporary reality in Kyiv. The words of my characters (in particular the ones you quote) are not my words, but those of typical individuals in Kyiv at that time. I am not able to force them to speak another language, one desirable to nationalist romantics, a language of propaganda, because this would be a falsification of reality, and I tried to present this reality as truthfully as possible. ... My main idea was that there existed various ideological tendencies in living Ukrainian reality and that we all need to search for a common Ukrainian path. How should I have presented this? By denying a voice to various tendencies, and immediately striking an iconic, propagandistic note? (DHA, Maria Lohaza, Humenna's reply, n. d.)

Another correspondent conceded that the book was "masterfully written," but admitted to being overcome by a "heavy and oppressive" feeling after reading the book:

Were there really no idealistic people with definite, firm views and national maturity, [...] who knew what they wanted and where to direct their efforts? ... I am not and never was an adherent of "purely rhetorical" [holoslivnoho] nationalism, and I am well acquainted with the parties of that day, but was it really necessary to present only negative types, to give the reader all the minuses and in so doing ignore those people who went to their native land out of deep patriotism, idealistic people who burned with a desire to live in and work for their native land, regardless of the difficult, dangerous circumstances! (DHA, Halyna Maksymiuk, 24 May 1956)

Humenna replied:

Not long ago there was a talk by Mr. Stakhiv in UVAN [Ukrains'ka Vil'na Akademiia Nauk - Ukrainian Free Academy of Sciences] on the subject of the "Underground in Donbas under the Germans." I would have liked you to hear this lecture. You would have seen how the memoirs of an underground

\footnotetext{
3 See, for example, the collection edited by Amar, et al. Discussions of the OUN can be found on the sites of Istorychna Pravda; Ukraina Moderna; and Memory at War. A special issue of Canadian Slavonic papers 54.3-4 (2012): 410-510 was devoted to contested memory of the war.
} 
activist who arrived for clandestine OUN work ... harmonize with my book. He even used my book as an example. He recounted that not only the Soviet people went through a complex process of reconstruction, rejecting old baggage and creating new, but those who brought new ideas, in the given instance clandestine activists from the OUN (people of firm ideas, in other words) ... also did not know what they wanted....

If nature produced only clearly delineated types (either positive or negative), our history would not look the way it does, and I would not be writing a letter from New York to Trenton, but maybe from Kyiv to Uzhhorod. ... It is my belief that all those who were active in Kyiv, who worked there, stayed and refused to leave, are all in some degree heroes, even those saleswomen who overcame German plans to starve the population of the city.... If the young generation lacks the strength of character to see what an insidious and many-headed enemy it faces, ... then it is incapable of struggle. It will see everyone who says "da" or "konechno" as an enemy, because it will be unable to distinguish the enemy from our own people.

Some found the criticism of Western Ukrainian nationalists entirely undifferentiated. One individual who had spent the interwar years in Czechoslovakia mentioned the earlier political emigration that had left after the defeat of the national state in the revolution of 1917-20. These people "carried on their shoulders the burden of the national struggle" in exile. They too, although forbidden by the Germans from doing so, "made their way back in an unorganized manner to their native land, worked in the cultural-educational field, served in the Ukrainian anti-German partisans, and were shot by the Germans." As for the OUN activists, he felt that history would, in the end, recognize their drive and sacrifice, "because they were the only ones who arrived in an organized fashion in Ukraine 'from the emigration' to work for the Ukrainian cause, even though they often went about that work in a manner that was not what it should have been. The notes concerning the negative assessment of their activities in your book are correct. ... However, you did not give positive types" (DHA, S. Nechai, 17 Jan. 1957).

When one correspondent complained that nationalist idealists were depicted as unserious teenagers, Humenna once more replied that one could not select a few phrases attributed to a particular protagonist and use them to condemn the author. Her goal was to show how Kyivites were at first disillusioned with "Westerners" and then gradually developed a mutual understanding with them: "I do not think that you can erase this painful but inevitable process from the Kyiv epic of those years. We must understand and analyze it. My book's goal was to show [the process] from the point of view of Kyiv's population, the simple ordinary person, so that future idealists would know how to approach these people and not imagine 
that they were all 'bolshevized' and needed to be 'taught national awareness'” (DHA, P. Riznyk, Humenna's reply 27 Sept. 1962).

The depiction of "Westerners" was not the only complaint. Personal sensitivity came through in other ways. One letter-writer, for example, charged Humenna with discrediting the peasants by focusing too heavily on the brewing of moonshine and the reluctance to help the people of Kyiv: "Soviet power drove the village into complete slavery and every year amplified the antagonism between the town and country. This was the case under Stalin and remains the case today. After the persecution and famine that the village suffered and continues to suffer, to demand self-sacrifice of villagers in order to save the town is, I think, inappropriate" (DHA, I. Shumuk, 17 July 1966). Humenna replied:

I have heard a lot of criticism ... but this is the first time I have been told that I treated the peasants badly. I cannot agree with this.... The peasants broke free and were overjoyed that the new occupation had not fettered them. And at that moment it became clear how rich our village was when not forced to give its bread to violators.... If it was insensitive to the city, this only indicates the hypocrisy of the Soviet slogan "removal of the difference between town and village." The city was insensitive when the village was swollen with hunger and corpses were strewn about the roads, streets and railway stations. Who could demand that the countryside rescue the town, and why? And is there anything of the kind in my work? ... Under the Germans no food imports to Kyiv were allowed. A proscription was placed on them. (DHA, I. Shumuk, Humenna's reply 29 July 1966)

There were, however, numerous positive responses. Halyna Kovalenko, Humenna's friend and the widow of the writer Yevhen Pluzhnyk, urged the author not to pay attention to critics who were motivated by the present political conjuncture:

I want to thank you for Kh. iar. I read it without missing a word. This is the best work written in emigration and you will never write anything better, so honest and truthful. I know that you are being strongly criticized for it, but do not pay attention, because only conjuncturalists will criticize you.... They have a different literature-Liubomyrs'kyi, for example, in which they can find unflinching types, heroism and endurance. But can one understand life from the works of Liubomyrs'kyi? I do not think so. You can dream something [like this] up, but after the first meeting with reality it will prove bankrupt and will collapse. It is not enough to say "we have come to our native land out of deep patriotism, we are principled people who burn with a desire to live on our native land and work for it, regardless of the difficult and dangerous circumstance." [...] These people were asked: "Fine, let's imagine that the Germans and Bolsheviks end by breaking each other's necks and an independent Ukraine emerges. What social order are you 
planning to introduce? [...] The underground revolutionary had no idea how to reply, because the OUN had never developed the question of the social order in an independent Ukraine. Not knowing what to say, he answered with a generality - the same order as in Franko's Spain. "Then that's fascism. Our people will not accept such an order, because we want a democratic one." The member of the underground [at that point] decided that he was dealing with a communist and even moved out of the house in fear. However, afterwards members of the underground themselves began thinking about the mysterious future order. (DHA, H. Kovalenko, 4 June 1956)

There were correspondents who concurred with the critique of nationalists, voiced by some of the novel's protagonists. One wrote: "I quite agree with your criticism of Galicians and all those Dontsovian idiots. I am a Galician myself" (DHA, Ivan Ivakiv, 11 Oct. 1964). One veteran of the Ukrainian Galician Army, although he considered the Germans "robbers and pillagers of the first order," who had come "to denationalize Ukraine and make it into Germany," also wrote approvingly of the way Humenna portrayed "the Galician cohort with their statute, or more correctly the false ideology of that madman Dontsov" (DHA, Iu. Zahorodnii, 15 Apr. 1956).

Humenna's admirers indicated that the book helped them to understand the German occupation; they saw no unfair criticism of nationalists, but only an attempt to raise important questions. One wrote: "As a Ukrainian, I am proud of you" (DHA, B. Boiko, 30 Jan. 1956). Another commented: "This is the first work I known that reflects the terrible period of German occupation in Ukraine. Reality is recreated truthfully, but through the prism of a specific world-view." He felt that the writer had every right to look at the world in any way she saw fit. As for "Westerners" in Kyiv, "they made many more mistakes than you describe, but those mistakes were INEVITABLE. . . . Iconography is of course unnecessary, although this is popular in the emigration; that is why literature here is so pedestrian, soporific. It never grasps or overwhelms the reader. . . Kh. iar is an interesting book, written attractively, and is necessary not only for our generation, but for the next" (DHA, O. Vashchenko, 26 July 1961). Another correspondent wrote: "I swallowed your book greedily. No historian has yet presented such a truthful picture of the 'rich' history of the Ukrainian liberation struggle, and it surely will not be written. . . This is a masterpiece about our lack of leadership. You deserve a monument from the whole Ukrainian nation in gratitude" (DHA, Hanna Hryhoriieva, 5 Feb. 1956). Yet another correspondent found the book "deep, serious, terrifying, full of medieval horror, epochal and valuable. None of our writers in this stormy time has described the invasion of our Trypillian Khreshchatyk Ravine by the twentieth-century's new Goths in such truthful artistic 
language. ... Even though I survive on a monthly pension of $\$ 60.00$, I want your Khreschatyi iar to be on the shelf of my modest library.... I am sending you a money order for \$4.00" (DHA, K. Danylenko-Danylevs'kyi, 10 May 1957).

As the above comments show, admirers were drawn to the book's depiction of wartime behaviour seldom described in émigré literature, in particular the behaviour of young nationalists, who, according to one correspondent, "saw themselves as loyal to their nation but in reality were essentially loyal to a party." This writer claimed to personally know many individuals referred to in the book from his time in Prague and considered it incorrect "to glorify them as heroes or martyrs" (DHA, Vasyl' Karalup, 13 Mar. 1956).

The already mentioned Halyna Kovalenko made a similar point. Future generations, she wrote, should be grateful for a book that helps them understand the wartime period. She appreciated the description of how the OUN attempted to assert itself in Kyiv. Members of the organization, in her view, were "deeply mistaken in their actions" toward the local population. These people "forgot that it was an unpardonable mistake to order people around in the same tone that the Germans used." She continued:

Kyiv was not waiting for orders from abroad, but for the infusion of new forces, and these had no business showing off and acting as superiors in the way they did.... The Ukrainian "Ubermenschen" will rage against you, but all this [rage] will be as useless as it was in the past! The greatest mistake was of their own making-in cooperating with the occupation-and now there is no point in remonstrating. You deserve sincere and heartfelt thanks for fixing the real events of Kyiv in 1941-43 in a literary work. (DHA, H. Kovalenko, 29 Jan. 1956)

Another correspondent appreciated the depiction of "the deadly conflict over the domination of this land between two pagan world powers," whose rapacious and destructive forces had sucked in the ideologically unformed, politically unorganized, and morally uncrystallized layers of the local population. He indicated that the "Ukrainian neopagans" had "crammed into Ukraine (and particularly into the capital Kyiv) together with the armies of the Western colonizer (this refers to students of Dmytro Dontsov, who preached the 'cult of the knife')?!" (DHA, A. Shapoval, 3 Oct. 1962).

The writer Halyna Zhurba, who lived in Kyiv from 1912 to 1919 and belonged to the modernist circles of that time, commented that the novel's autobiographical element added to the book's truthfulness: 
[0]ur "patriots" love to spread various lies that make them look "heroic." Dokia did a fine thing by writing how things were and how they should be described in sophisticated books. We have so much of the other [kind of writing] with its various cheap "gildings" that literature has become marketplace trash. It is chock-full of heroes, famous people, brilliant victories. ... Of course, there was heroism, and a lot of it, maybe more selfsacrificing heroism than any other nation showed during that war, but it belonged to those who died in silence, . . . while the "heroes" appeared abroad where they began to proclaim their "heroism." (DHA, Halyna Zhurba, n. d.)

The literary scholar and folklorist Petro Odarchanko, who also came from Eastern Ukraine and had been imprisoned and exiled to Siberia in the 1930s, read the book as a roman à clef: "You brilliantly painted the comic pain of Zhuks (Shchuka and Shchuchka). I also found A. Liubchenko (A. Vidomyi) and A. Kolomyiets' in your work." Although he asked who the living prototypes were for the book's other heroes, Humenna rejected an excessively literal reading of the book, countering that it was, after all, a novel (DHA, Petro Odarchanko, 2 Feb. 1956).

The views of these letter writers were echoed in the press coverage. The newspaper and journal articles often concentrated on the portrayal of the leading protagonist, Mariana. The writer and critic Anatol' Iuryniak, an Eastern Ukrainian who worked as an editor of the social-democratic Ukrainski visti (Ukrainian News), interpreted Mariana as a protagonist focused on "herself and her hopeless boredom." Humenna's public response was that Mariana was a product of Soviet reality. As such, she "lacked required reading, teachers, and created out of herself and her thoughts an idealistic, non-materialist spirituality." Humenna rejected the critic's call for an unambiguously positive hero (DHA, A. Iuryniak, Humenna's response, 28 Mar. 1965). Here, as she did in a number of letters to various correspondents, Humenna insisted that her characterization was meant to show how individuality is the product of hard effort and must be gained in struggling against the leveling processes in Soviet life.

The well-known critic Iurii Lavrinenko, who was also from Eastern Ukraine and had been imprisoned in the 1930s in a concentration camp in Norilsk, Siberia, noted the book's cinema-chronicle style and authentic detail. He defined Mariana's position as "a hostile neutrality" toward invaders of her land, "a passive resistance" that encapsulated "the nation's wise instinct." However, he faulted the protagonist for blindness toward the heroism of activists (Lavrinenko 3) In his view, Mariana expects a "readymade, free Ukrainian state" from the Germans. She therefore fails to realize that "the Germans were not prepared to shed their blood for Ukrainian freedom or independence if Ukrainians themselves did not do so." 
Humenna commented in the margin of her copy of the article: "Where is this [in the book]?" His comment that Mariana subscribed to the credo "I am not to blame" is also answered in the margin with: "These words are not in the book." Lavrinenko saw Mariana as locked in a spiritual bunker, waiting, directing hostile neutrality and acid criticism toward "the people of active resistance, who await another author and another book" (DHA, Lavrinenko).

Like the correspondence, the public discourse around Humenna's novel focused heavily on the author's attitude toward Galician and "Western" nationalists. One writer was particularly offended by the use of the terms fascist and chauvinist to describe nationalists. He pointed out that many died at the hands of the Gestapo, and that they conducted both anti-German and anti-Bolshevik work. Ukrainian nationalism, he wrote, "is not fascism, or chauvinism, and is not Nazism, but only the struggle for liberation from captivity of one's native land, and is far from the weird racist theories of Hitler or Mussolini." He saw the "ideological chaos" in Mariana's mind as resulting from Soviet propaganda. To him, her way of thinking appeared close to bolshevism (DHA, Ryndyk).

A second writer saw the meeting of Eastern and Western Ukraine as the book's main idea, and took from the text an optimistic message that a people who had survived so many millennia would continue to exist. The "forms change but the essence remains the same. From ashes and ruins this essence arises anew.... Individual and collective internal strength is the guiding idea in Khreshchatyi iar. Awareness of this force transforms pessimism into optimism, which is the final chord in the work" (DHA, 0. Chernova).

Humenna dismissed a review by H. Zavadovych, who interpreted the work as depicting Easterners who are unsure about what kind of Ukraine they desire: "Sometimes they really seem to want a Soviet Ukraine, even within the USSR's boundaries, only with wise and honest communists in government and with broad democracy, without a bloody Bolshevik terror." Humenna commented in the margin: "He didn't understand it." The reviewer felt that the protagonist Mykhailo Ivashko joined the party only for a scholarly career, was unable to hide from the Germans and was liquidated. Against this comment Humenna wrote: "He understood that part." The reviewer also commented that some Soviet people had been left behind to work as spies, or to make life for the population worse-VassaValentyna Stupina, Kalashnikov, and Pomazanov among them. Some were loyal to all regimes, like Halyna Poltavchenko, Semen Kucheriavyi, Hnat Zahnybida, and the film director Viktor Prudyus. Humenna wrote in the margins: "He understood that part." 
Like Odarchenko, Zavadovych read the book as a roman à clef. He commented, for example, that the film director Viktor Prudyus was the well-known Ivan Kavaleridze, who realized that he would not have a career in Germany and therefore hoped for and decided to wait for the return of the Soviets. Kavaleridze did not collaborate and avoided all work under German occupation. Humenna paints this protagonist sympathetically, a fact that did not appeal to Zavadovych, who saw him as a negative character and informed that his prototype Kavaleridze continued to live well in the USSR. In fact, Kavaleridze was prevented from making any more films after the Second World War, many of his sculptures were removed and his creative activities significantly curtailed. The reviewer also thought that the character of Zahnybida was based on a lecturer who had been repressed and that Vasylyna Stupina was based on a character who was liquidated by the Germans on the mistaken assumption that she was a Bolshevik agent. Humenna, as we have seen, dismissed this search for real people behind novelistic characters. Zavadovych applied a narrowly partisan approach. He complained that the real Ukrainian elite and "true patriots" were not represented by Humenna, and therefore considered the novel "one-sided and not useful for the Ukrainian cause." He found that the focus on Mariana's complex feelings "made the book boring" (31).

One reviewer complained of the "strange style," with dozens of "similar" characters, and "facts so grey" that they are scarcely worth recording. The complaint here was that the author refuses to say who Mariana is and what she is doing in the novel, that "nationalists" are ridiculed for being unable to communicate with the general population, and that no attempt is made to justify their actions and desires (Romulius). Bohdan Romanenchuk, an editor and critic who came from Western Ukraine, called the work tendentious and Humenna hostile to "Westerners." He mentioned only three exceptions, Olena (Olena Teliha), Oleh (Oleh Ol'zhych), and Avenir (Avenir Kolomyiets'), all of whom were associated with the work of the OUN in Kyiv. He stated that her novel takes a "mocking, contemptuous, and negative attitude" to all others (Romanenchuk 139). In his opinion, Humenna finds no positive types among nationalists, sees nothing good in contemporaries, and provides no way forward. A third reviewer, who offered the information that he was one of those who went east in 1941, considered the clash between Western and Eastern Ukrainians the book's most interesting element. He agreed that there were all kinds among "Westerners," including "political primitives and speculators," but most, according to him, were idealists. An insightful commentator, he pointed out that the novel describes many activists, both inside and outside the OUN, and as such can hardly be said to lack "positive," politically engaged figures. He concluded that the book should be read by all who want 
to see Ukraine as it really is and who wish to deal with this reality (Mykolyn).

It is telling that, like the correspondents, almost all reviewers with a strongly negative opinion of the novel failed to distinguish between Mariana's attitudes and those of the author; they viewed both as expressions of a "bolshevized" or Russified Eastern Ukraine. A reviewer for the newspaper Ameryka (America) writing in 1958 described Mariana as a classic "non-party Bolshevik" type and drew attention to Mariana's opposition to Kyiv's Jewishness. Mariana's screen-play is not accepted for publication by a Jewish editor ("Were any accepted?" asks the reviewer sarcastically), but she eventually "forgives not only the guilty party but all of Jewish Kyiv." The reviewer argues that the escape of Jews from the Germans was made more difficult by the Soviet regime because it knew that the shooting of Jews by Germans would cause international outrage and would encourage sympathy for Moscow. At the same time, the Soviet regime "provoked the local population, claiming that all evils suffered by the population under Bolshevik occupation were the fault of the Jews." The reviewer calls on Jews to take an interest in the book, suggesting that it is anti-Semitic (DHA, -enko).

Humenna was incensed by this review and wrote an angry reply, which the newspaper did not publish. Her reply to the Ameryka article and to another article by 0. -ko in Ukrainets' (Ukrainian) appeared as an open letter ("Vidkrytyi lyst") in the publication Ukrains'kyi prometei (Ukrainian Prometheus, no. 24, 1958). In it she explained that she wrote not according to someone's directives, but according to the way she saw the world. The Soviets had called her a bourgeois nationalist and "kulak" writer, and accused her of slandering Soviet reality, and now critics in the West were calling her a non-party Bolshevik, a communist, an anti-Semite and a hater of "Western" nationalists. She objected to the insinuation that the book was anti-Semitic. Around this time the critic Hryhorii Kostiuk wrote to Humenna that Prof. Friedman of Columbia University had read Khreshchatyi iar and found nothing anti-Semitic in it (DHA, H. Kostiuk, 17 Mar. 1957). Humenna also rejected the argument that Jews were prevented from leaving Kyiv, pointing out that many who wanted to escape were provided with the opportunity to do so. She once more defined her task in the novel:

My authorial task lay in showing, step by step, the very complicated process that took place in the souls of all citizens under Soviet rule as the regime was collapsing and they were confronted with new, often unfamiliar ideas. I made an effort to place the rich and variegated chaos of that time into a compositional frame (because it is not a diary) with a small number of characters, in order to show how, in the meeting with the West, two 
different worlds and their ways of thinking collided, grappled with one another, and interpenetrated. Who is it that forbids this process from being analyzed? (DHA, -enko, Humenna's response, n. d.)

Humenna was particularly irked by the description of her main character as a "non-party Bolshevik," since this kind of slur could be applied to any protagonist who thought differently from a particular critic. She informed readers that the leading Soviet Ukrainian literary newspaper, Kyiv's Literaturna hazeta (Literary Gazette) had denounced her Khreshchatyi iar as anti-Soviet in issues 99 and 100 from 1958.

The underlying vision of Ukraine in Humenna's work is pluralist. The author sees nations as composite entities created over hundreds of years from different constituent groups. In her view, there are no homogeneous nations; each is the product of a complex intermingling of peoples and traditions. She saw herself and her people as the product of various historical periods. At points in her unpublished diary and her published memoirs she gives concrete expression to this idea by summoning all her ancestors, even those from prehistoric times. This vision of Ukrainian identity stands in opposition to the kind of essentialism propagated in the 1930s by some writers.

In 1958 Dontsov, who had been the leading critic and the inspirer of many in the OUN during the 1930s and 1940s, wrote an attack on modernism entitled "Moderna literature rozkladu" (The Modern Literature of Decay), in which he denounced a long list of contemporary authors as modernists, including Ihor Kostets'kyi, Sviatoslav Hordyns'kyi, Yurii Kosach, Volodymyr Vynnychenko, Teodosii Osmachka, Humenna, Jean-Paul Sartre, Francoise Sagan, and Albert Camus. His dissatisfaction with modernism was based on what he saw as its pessimism, skepticism, atheism, hedonism, "plebeian" aesthetic, lack of heroism, excessive interest in sexuality, and "love for the little individual." Humenna's novel was singled out for attack. Dontsov's discomfort with her writing, as with modernism in general, stemmed from what he saw as the pursuit of complexity and the de-heroizing tone in contemporary writing, both of which, he felt, sapped the spirit of self-sacrifice. He preferred the portrayal of simple, clear ideals. The diversity of the Ukrainian population's response to war, as depicted in Humenna, with its recognition of regional variation and conflicting opinions, appears to have irritated him, although it is not clear whether he had even read the novel. Vadym Svaroh defended Khreshchatyi iar against this attack, saying that the public was "fed-up" with agitprop literature: "It is time we looked at ourselves with self-criticism, without painting ourselves in heroic colours, but thinking about our faults and mistakes. This is exactly what Humenna does." He goes on to argue that 
in the struggle between German and Russian totalitarianisms the primary task of Ukrainians was to survive, because the country was too weak to play an independent political role (Svaroh, "Na uvazi" n. p.).

It is worth noting that in the range of issues raised by these responses to Humenna's book the tragic fate of Ukraine's Jews, and the role of Ukrainians as witnesses, bystanders, or perpetrators of crimes (something that Humenna indicates in her novel) is not contested. It is tacitly accepted by all correspondents and reviewers. The painful, unresolved issue is the clash between Eastern and Western Ukrainians. Discussion on this topic was sharp, but civil. Humenna's direct, honest interaction with her readers is also worth indicating. Her respectfulness toward all the correspondents and reviewers she answered displays a commitment to open discourse and a faith in public dialogue as a path to common understanding.

The unwillingness of many readers to distinguish between advocacy and representation emerges from these exchanges as a constant problem. The author argued many times that her views were not necessarily those of her protagonists, and that as a necessary step toward understanding what had happened during the war it was vital for readers to be confronted with books that represented life in Eastern Ukraine in all its complexity. The book was conceived as an alternative to the simplistic ideas and orthodoxies being fed to readers by political parties. As such it presented a reality that many were unwilling to confront. For the author to remain silent when her personal experience contradicted a political orthodoxy would have been to betray her vocation as a writer.

A more concrete issue, and the subtext of many responses, was the idea of the nation as a homogeneous community and the desire to see this homogeneity reflected in literature. This idea revealed a yearning for ideological unity and solidarity; it presupposed a "tribe" that shared values, submitted to a single authority, and acted in concert. Humenna was in revolt against this kind of fundamentalism, which denied or ignored alternative viewpoints. The fragmented form of her work results directly from an attempt to integrate multiple views. Therefore, the book could not satisfy those who sought the security of a simple message, or who were offended by the voicing of points of view that contradicted their own. Reality, Humenna implicitly argued, was not what these readers imagined it to be; nor would reality disappear if books represented it in the way these readers preferred. Any kind of fundamentalism is threatened by diversity, by the idea of evolving and changing norms. The concept of nation favoured by Humenna-democratically diverse, based on the idea of evolutionary change-was inimical to the thinking of some of her respondents. Simply put, their myth of nation did not accord with Humenna's. On the other hand, many readers liked her presentation of the wartime experience and 
immediately understood her deeper purpose. They did not treat her work as apostasy, but saw it as a welcome expansion of the concept of nation and a more complex picture of the wartime experience.

Humenna's novel made a major contribution to her readership's understanding of the war, the East-West divide, and the role of OUN activists. At the time she wrote and published her novel, fundamentalists within OUN were being criticized by leading writers in emigration. The latter were all dubbed "modernists" by Dontsov. The stylistically most innovative writers, such as Kostets'kyi, Kosach, and the New York Group, shunned didacticism and appeared uninterested-at least overtly-in the national question. Like the works of these postwar "modernists," Humenna's novel sought to bring new insights to readers, to dramatize what may not have been thought but needed considering. The novel allowed readers to grasp and assimilate another, more complex view of the world. A great many readers-even those who voiced criticismsappreciated the book for these reasons.

\section{Works Cited}

Amar, T. S., I. Bachyns'kyi, and Ia. Hrytsak, eds. Strasti za Banderoiu. Kyiv: Hrani-T, 2007. Print.

Chernova, O. "Hromadianka tysiacholit." Svoboda 3 May 1956. Print.

Dontsov, Dmytro. "Moderna literatura rozkladu." Literatura $i$ mystetstvo, supplement to Homin Ukrainy. 26 July 1958. Print.

Humenna, Dokia. Dar Evdotei: Ispyt pamiati. 2 vols. Baltimore-Toronto: Smoloskyp, 1990. Print.

---. Khreshchatyi iar (Kyiv 1941-43: Roman-Khronika). New York: Slovo, 1956. Print.

---. "Materiial do povisty Hnizdo nad bezodneiu." Dokia Humenna Archive, Ukrainian Cultural and Education Centre (Oseredok), Winnipeg. Print.

---. Dity chumatskoho shliaku. Roman u 4 knyhakh. Munich: Vydavnystvo "Ukrainska trybuna," 1948. Print.

-enko, Hr. "Dumky, shcho pryishly z Khreshchatoho iaru." Ameryka. 16 May 1958. Print.

0.-ko "Pro dvi khyzhky." Ukrainets 23 Feb. 1958. Print.

Romanenchuk, B. "Dokia Humenna, Khreshchatyi iar." Kyiv 3 May 1956: 139-40. Print.

Ryndyk, S. "Chuzhymy dorohamy." Ukrainske zhyttia 23 Nov. 1957. Print.

Samchuk, Ulas. Piat po dvanadtsiatii. Buenos Aires: Vydavnytstvo Mykoly Denysiuka, 1954. Print.

Shkandrij, Myroslav. "Dokia Humenna's Representation of the Second World War in Her Novel and Diary." Harvard Ukrainian Studies 32.1-4 (2010-2011): 1-15. Print.

Shkandrij, Myroslav. Ukrainian Nationalism: Politics, Ideology, and Literature, 19291956. New Haven and London: Yale University Press, 2015. Print. 
Svaroh, Vadym. "Mariana Veresoch i ii pryiateli. (Do problem literaturnoho heroia)." Novi dni (October 1964): 15-18. Print.

Shankovs'kyi, Lev. Pokhidni hrupy OUN: Prychynky do istorii pokhidnykh hrup OUN na tsentral'nykh zemliakh Ukrainy $v$ 1941-1943 rr. Munich: Ukrains'kyi samostiinyk, 1958. Print.

Zavadovych, H. "Povist pro Kyiv.” Visnyk (April 1956): 29-31. Print.

Zhyla, Volodymyr. "Dokiia Humenna ta ii doistorychnyi zhanr v literaturi." Verkhovyna: Literaturna mozaika 17 (2002): 12-20. Print. 
(c) 2016 East/West: Journal of Ukrainian Studies (ewjus.com) ISSN 2292-7956 Volume III, No. 1 (2016) 